DOI https://doi.org/10.32837/app.v0i67.1163

UDC 101: 1.316

\author{
N. N. Yagublu \\ orcid.org/0000-0002-0382-6495 \\ Doctoral Student at the Department of International Relations \\ Baku State University
}

\title{
IS LIBERTARIANISM THE NEW FUTURE? ANALYZING IDEOLOGICAL AND PHILOSOPHICAL ROOTS OF THE LIBERTARIAN THOUGHT IN THE UNITED STATES
}

Introduction. In modern history the U.S. has been one of the prominent places where new ideologies and approaches emerged or already established thoughts evolved to different deviations of themselves.

American uniqueness manifests itself in many diverse forms; surely one of them is being imitated and desired even though pursuing a widely criticized foreign policy and having a track record of controversial military interventions. Many elements of the U.S. actions are condemned and even globally despised, but attraction for the country never ceases. Given the undeniable fact of American influence, it is self-evident that what happens in the U.S. impacts the other regions of the globe. Newly occurring and practiced trends in lifestyle, technology, music, fashion and many more in the country significantly affects the world, if not determine them. The new movements and tendencies in politics are no exception.

Recently, with the rise of populism and anti-establishment rhetoric in the U.S., many of the historically accepted and observed notions in the country's politics were heavily questioned and challenged by the masses of people. As the resentment grew, various alternative ideas were offered and promoted as solutions. Progressivism, economic nationalism, patriotism, different kinds of leftist and socialist approaches, new versions of identity politics and many others became prevalent in different sections of the society. And one of them surely was libertarianism.

Libertarianism as a political ideology glorifies the notions of freedom, liberty and individualism. For them, the most important value is being absolutely free to do what you want and how you want. With freedom they mean getting rid of any kind of coercion, especially the one imposed externally. In broader political-institutional perspective the main source of this external coercion is government, therefore libertarians loathe the concept of government (Brennan, 2012, pp.1-2). For them, government is the big evil, so all the aspirations to limit its role is beneficial and auspicious.

But generally, libertarians vary in their level of tolerance to the size of government they would like to see; for example, there are ones who see anarcho-capitalism as the only best option, and there are ones who deem it necessary to have at least some form of higher legal institutions that oversee the activities going on in the country.

Actually, this kind of negative and distrustful attitude toward government is quite widespread among the population in the United States. From the times of colonization and the American War of Independence till many different developments and injustices, the laws and overall mindset of the people formed in a way that made them always question the government's decisions. The American mentality of being skeptical of the government actually was the basis of many different controversial laws. For instance, the Second Amendment of the Constitution - the right to bear arms was authorized to prevent any possible tyranny of the government (Kopel, 2016). Libertarians do not think that democracy is a magic tool that precludes any type of possible bad outcomes. Indeed the pages of history are full of moments where democracies have turned into monstrous regimes; Nazi Germany being the most prominent example of that.

Democracy doesn't guarantee that the best option for each single individual will be provided, although it may create such illusion in people's minds. Many horrific periods in the country's past happened under such system; racial segregation was implemented under democracy, slavery was permitted during the time where there was free elections and freedom of speech. So, democracy is not the sole pathway to absolute happiness and prosperity; abolishing or limiting the role of big ruling authority such as government who makes decisions for the masses of people is. 
Libertarianism and classical liberalism can be used interchangeably as the main tenets of both ideologies almost look identical. If to look at historical perspective, after the advent of new trends and waves in liberalism such as social liberalism (which puts great emphasis on equality and needs of the dispossessed), the people whose only concern was about individual liberties and freedoms wanted to distinguish themselves and stick to the very old cores of the ideology (Smith, 2013, pp. 7-8). So, in $19^{\text {th }}$ century classical liberalism diverged itself and started to advocate for specific policy positions such as minimal state, laissez-faire economic system and strong private property rights. The role of the Industrial Revolution in the formation and enhancement of this movement was also important (Encyclopedia, 2020).

\section{Why minimal state?}

Surely, the main tendency that unites all libertarians is their vehement distrust in the government. Government is bad because it is totally unreasonable to think that some small group of elected officials will make decisions that suit to the needs of every single individual in the country. One centralized authority cannot and should not take action on their own and decide for the masses of people. If they do, they will act out of inadequate knowledge. Libertarians think that human beings are just too ignorant to know what each individual wants and lacks. Indeed, persons alone will make their own choices out of their own self-interests and everything will play out well this way (Van Dyke, 1995, p. 105). It is the most useful way for society to develop and flourish.

There is always corruption to some degree and if all the power is accumulated on one hand, this authority will be problematic. But if the authority is dispersed and diversified then it will be overall more positive. As there is free market and independent choice, people will naturally avoid or boycott the one who breaches the law, and reward the ones who comply with the code of conduct. This approach alone will ignite the initiative in people to act more responsibly. Related to that, libertarians are also supportive of definite term limits for people holding office (Van Dyke, 1995, p. 111).

\section{Negative freedom vs. positive freedom}

It must be noted that adherents of libertarianism mainly care about negative freedom rather than positive freedom. Negative freedom simply means freedom from any kind of external constraint. For example, if government restricts people's freedom of movement and forbids them from travelling from one city to another within the same country, then it is a clear violation of negative liberty. Nevertheless, if some people lack financial resources to travel but official laws do not bar them from doing that, then it is related to positive liberty. Roughly, positive liberty can be characterized as having capacity to act upon one's free will (Ashford and Davies, 2011, pp.97-100). But libertarians do not really care about it that much; for them absence of external obstacles and barriers are the most important thing. Libertarians really embrace John Locke's concept of everyone having right to "Life, Liberty and Property" and they consider it inalienable. If someone is poor, it is their own problem. They must take personal responsibility and work hard to fulfill their potential. No one owes anybody anything.

\section{Other main characteristics of the libertarian thought}

Libertarians favor laissez-faire economic system. They are against any kind of government interference to free markets assuming all artificial action from outside will eventually yield negative consequences, contrary to how it was intended. So, decreasing regulations, taxes and subsidies are welcomed. Classical liberals emphasize the importance of personal responsibility and dislike collectivism and social justice. Artificially trying to provide social justice is unjust. It is totally fair to suffer losses if you make bad choices, and it is totally appropriate to achieve big gains if you make good, smart life choices. They see the rules of economic system as in a sports game. For example in basketball, one is victorious if he wins. Anyone who intends to bring social justice through interfering the game in favor of the losing side will violate the rules. Rewarding those who lose and punishing those who really put in effort to win will be discouraging, frustrating and counter-productive in long run. Loser should lose in order to learn from his mistakes, train and develop himself to succeed in next games. Trying to change the situation in favor of the defeated will deteriorate the whole natural process. People won't be motivated to achieve and accomplish if they are not awarded or if their victory is forcibly taken away from them. It is disheartening. 
If there is wealth disparity, it means there is successful entrepreneurship. And entrepreneurship occupies very important place in libertarian ideology. They are the ones who stand up against the tyranny of the government. If private businesses and corporations get strengthened then the centralized authority will not be able to draft constraining and coercive policies, but it will need to make concessions. Entrepreneurs create jobs and open work places. Without them the economy wouldn't flourish and the overall well-being of the country would be greatly diminished.

Libertarians ignore the questions about equality of opportunity. They even think that there should be no punitive measures by the government against the racial discrimination when it comes to hiring, renting, signing deals etc. Racial, ethnic, gender or religious discrimination are choices independently made by individuals (Van Dyke, 1995, p.116). If the justice is concerned, markets will eventually make bad people good. In a free economy, the success of profit-oriented actors is determined by demand-supply relationship. If a person continuously exhibits wrong and unacceptable behavior, then the public will punish him through refusing to purchase his goods or protesting.

Libertarianism in its very core centered on individualism. It decries the idea of social responsibility. In economy free agents make decisions based on their own self-interests. Therefore, freedom of contract is essential; employers should be able to easily hire and sack if it will enhance their profits. And minimum wage laws shouldn't be imposed, as forcing businesses to comply with it is pure violation of their freedom. They can pay whomever, how much they consider necessary. Enforcing high and costly minimum wage requirements can be very detrimental; if the company is obliged to pay its employees more than the supposed amount, then it may no longer be able to sustain paying for the existing workforce. And as the company may no longer be able to afford, then it must fire some number of its workers. So, unemployment will rise, workload of the employed will increase. Besides, minimum wage demands are untenable and unfair, as there is myriad of jobs and positions where the authentic labor cost is much less. Under this condition, for multitude of posts that do not require sophisticated skillset, the company will have to pay more than it should. Moreover, there are many young people whose only concern is getting some experience for their own careers. They will also be negatively affected, as it will be much harder to be recruited due to such provisions.

Libertarians are critical of the inclusion and diversity programs, emphasizing the importance of merit-based system. The only path forward is employing those who are the best equipped. It will encourage others to work hard, better themselves and expand their skillset. Thus, if any racial, ethnic group or gender is underrepresented in some workplace it ought not to be interpreted as there is bias against them; it means currently the existing workforce are comprised of the ones who truly deserve to be there, regardless of their identities.

Self-reliance, egoism and personal responsibility are the several main fundaments of the libertarian thought. And some libertarians are more anarchist than others. For example, there are some who oppose licensing of persons for various professions. For them licensing individuals to be doctors, or to sell food products and open restaurants is redundant. Even during the 2016 presidential debates in the Libertarian Party, several candidates belittled the idea of granting authorizing documents for people who want to drive. Candidate Darryl Perry compared it to using toast machine when he was asked if someone should have government-issued license to drive a car. "What is next? Requiring a license to make toast in your own toaster?!" he responded (User Clip, 2018).

Although there are libertarians who truly hate the notion of government, many of them agree on the point that there should be some type of higher institutions who oversee the interactions and operations going on within the state. Because of that many of them support the idea of at least having the judiciary, police and military. Besides, even though there are ones who utterly claim that the very essence of the concept of taxation is theft, they concede the inevitability of collecting taxes at certain - preferably lower - rate in order to fund such supervisory entities.

Moreover, classical liberals prefer flat tax over progressive income tax considering latter discouraging. Progressive income tax punishes winners, deprives them of their will and motivation to engage in business activities. If entrepreneurs have more freedom and wealth, they will open new workplaces and hire more people in even bigger numbers.

The support for the role of moral norms in a society varies among libertarians. Many of them accept the importance of social units such as family, church and charity but only if they are voluntary. 
For example, American author and political analyst Lew Rockwell says that freedom from government doesn't mean freedom from ethical and social norms. "Authority will always be necessary in society," he argues (Rockwell, 1990, p.36).

Libertarians dislike the very idea of welfare state. It is an effort to promote "artificial justice" through redistributive taxing policies. In order to continuously provide social services (such as socialized healthcare, free education, daycare, unemployment benefits, free housing and accommodation etc.) government has to increase taxes to certain significant level. It is burdensome for all people and unfair. It will negatively impact entrepreneurship overall. If there are poor people in need, then private charities and organizations should take care of them.

Milton Friedman says that "nobody spends somebody else's money as carefully as he spends his own" (Boaz, 2002, p. 55). If something is free, people tend to lavishly use it. But if they pay from their own pockets, then they are more careful and controlled in their decisions. According to classical liberals, although the notion of welfare system may seem alluring, it damages the state and society in long run. For example, unemployment benefits kill the initiative to work and contribute. Free healthcare eventually lowers the quality of provided services; patients are put in long, endless queues, and drive for innovation and new scientific breakthroughs are crippled. Overall, in welfare states most people take advantage of the system, abuse it and cheat for their own interests.

Instead of welfare system, some classical liberals such as M. Friedman suggests implementation of a negative income tax. In such structure, certain income level is set and people in the lower margin of it would recieve supplementary payments. Therefore, taxes would be levied on only those who earn more than the set amount (Rogers, 1988, p. 90).

There are many libertarians who want to abolish the Department of Education. They think the government shouldn't administer education; private, profit-oriented entities should be able to act freely (Libertarian Party on Education, 2018). As in medical services, lack of profit-oriented actors, and therefore competition in education system will entail lower quality of supply. At the very minimum, government may inspect to some degree the activities of these private actors, but execution shouldn't be on its own hands. However, support for even this level of supervision is still controversial among libertarians.

\section{Criticism}

When expressing their disdain for the existence of the government, libertarians tend to downplay or neglect many different variables and factors influencing the general well-being of a society. Surely, desire to limit the role of government to allow the individual liberties to flourish is understandable and in principle justifiable. However, it is not as simple as it sounds. In societies, where the human capital index and literacy rates are low, absolute freedom may lead to unintended consequences, similar to what Thomas Hobbes described in his "state of nature" notion. In this concept, one postulates from a hypothetical scenario how the life conditions would be in the absence of a civil society and one common ruling authority. In this anarchic situation everyone could do whatever they want without the fear of getting punished. Without any punitive measures in place, there would be "continual fear and danger of violent death" and life of a man would be "solitary, poor, nasty, brutish, and short" he says. Thereby, he alluded the idea that "no one has liberty, because everyone has it". Thomas Hobbes then proposes a solution which became known as "social contract theory". According to this notion, people should cede some of their rights and freedoms to common authority in exchange for their safety, justice, protection of their rights, and for the general stability of the society (Lloyd and Sreedhar, 2019). So, if this side of the issue is taken into account and analyzed, having a ruling authority like government is not inherently a bad thing, but the solution to avoid further harm and catastrophe.

As it is seen from the above-mentioned analogy, one can conclude that libertarianism lacks the trait of universality. Applying this model can result in a disaster in various regions of the world. Especially, in undeveloped countries where societies lack "democracy habits". For example, in Iraq aspirations to build a democracy created massive turmoil where the opportunistic, radical religious groups got strengthened and committed heinous, vicious acts. In Libya, after the fall of Dictator Gaddafi bloody, civil war ensued. Desires to build a secular country ignited violent groups to fight each other endlessly, and tens of thousands of people suffered. After the fall of central government, 
these countries couldn't recover, and violence and bloodshed haven't ceased. These facts again illustrate the applicability of the main libertarian value is not globally plausible yet.

Libertarians' outright aversion to the idea of welfare state, together with their negligence and hesitation to the notions of equal opportunity and social justice are also contentious. Surely, hard work, self-reliance and discipline are great virtues and can significantly facilitate one's life for the better. But life is so complex and nuanced that offering just these values to myriad of different issues would be just over-simplification and superficial. Overall poverty, systemic societal discrimination, persons with bad upbringing, genetic disorders, illnesses and many other challenges in this nature cannot be solved merely by "working hard". It could be a very effective life philosophy to live by, but solely relying on this assumption when it comes to drafting government policies for millions of people from diverse backgrounds would be ostensible and inadequate. Besides, the life is full of unexpected situations and developments where one's well-being can be substantially imperiled by the sudden outbreak of multitude of hardships. Hardships that may lead to financial bankruptcy and severe impairment of one's daily functioning, such as costly treatment of a serious disease. So, having some type of social safety net indeed seems sensible.

To really get the grasp of the significance of the issue of social justice, the great thought experiment by John Rawls called 'original position' can be utilized. Original position is a hypothetical scenario where the individuals behind the 'veil of ignorance' decide what kind of society they would like to establish before they were born. In this imagined scenario, an individual lacks prior knowledge on which race, gender and ethnicity they will belong to, and which social and economic status they will have. As this theory suggests, because the person will decide from the position of insufficient knowledge about himself, he will not take into account his currently held personal interests. It will force him to be fairer and have empathy, since potentially he could also suffer at the end (Rawls, 1999, pp. 10-12).

As libertarians oppose social safety programs, how the fate of the people with unfavorable conditions would be still remains uncertain. Libertarians contend private charities can cope with the issue, but it is highly unrealistic. And their claim that in welfare states many people exploit the system cannot be a rationalization to reject it, as in the current system many individuals also take advantage of the order. For example, the people who were born in rich families did nothing to acquire massive amounts of wealth; they just got lucky. They didn't work hard or took personal responsibility to succeed in life, yet they are far ahead of many others.

Classical liberals favor free market economy with less or no government intervention. They mostly ground their argument on Adam Smith's famous concept 'invisible hand'. According to this notion, society is better off when everybody works for their own self-interest. As counter-intuitive as it sounds, the theory argues that aspirations of individual actors to maximize their own profits create unintended social benefits (Heath, 2017). One of the great thought leaders of the libertarian economy, Milton Friedman later denoted the same argument by saying it is the "greed" that drives competition, innovation and prosperity (Safvio, 2007).

Surely, there is some truth to certain extent in this idea, and starting from the second half of XX century world economy greatly benefitted from it. However, the economic crises in recent decades made people re-consider some Keynesian principles, such as encouraging government interference during the times of recession.

There were many instances where the greed led to unwanted negative outcomes, and markets couldn't balance themselves. The Great Recession of late 2000s which began by the Financial Crisis in 2007 is the most prominent example of this. Continuous tax cuts and deregulation (including the repeal of the Glass-Steagall Act) together with natural economic factors such as changes in oil prices produced the biggest economic shock after the 1930s' economic collapse.

Some part of the problem with the libertarian thinking of the economy is that they ignore behavioral economics. In traditional economics, it is assumed that people are rational, and they make rational decisions. But in reality, people do not always make choices that continuously maximize their own well-being and happiness. Humans tend to have biases, blind spots and they can be misguided or enticed by various factors. As an example, according to several theories of classical economics, when entrepreneurs and high-income earners get tax breaks and make more money, they open new work 
places, invest more in economy and spend more. Therefore, rate of unemployment decreases and money circulation accelerates. However, for behavioral economics it is not always the case - because often when people acquire more, they want to save more. They may keep their capital in banks, transfer their wealth to offshore accounts or move their businesses to other countries where the cost of production is lower. So, it illustrates that the traditional approach is not always the most sensible way; what is thought to be hypothetically true in theory often is contradicted by the reality.

Libertarians are opposed to public ownership of parks, public housing, and trade laws including tariffs and import quotas. They are critical of government subsidies and support for agriculture as well, regarding market forces should determine the dynamics there. However, such approach could be particularly very harmful because when it comes to public safety and preservation of nature, personal interests and greed can get in the way of improving the welfare of the community. Private entities in order to increase their profit may undermine the basic environmental principles, pollute and damage the landscape. All living organisms might be negatively affected because of the reckless or purposefully harmful ways of conduct. Issues with clean air and water might occur, plant and animal lives could be jeopardized, and overall hygiene can be deteriorated. So, there is wisdom for calling a higher authoritative body to regulate the affairs in this sphere.

When it comes to agriculture and farming, there are several important points to consider. Nearly all countries in the world pay special importance to this area. And it is not in vain, but well-founded. Agriculture is the backbone of an economy; without a properly planned agricultural policy, country may struggle in future. It plays a pivotal role because in the simplest terms - people would be starving without food. If new trade barriers, sanctions and other restrictions related to food products are put on a country from outside, it may get hurt. So every state tries to self-sustain itself and diminish the level of its possible vulnerability. It is the main reason why countries vigorously pay attention to this sector. Therefore, here letting market forces and private interest to dictate would be precarious and risky. Furthermore, eliminating government control in terms of regulations and inspections would be detrimental and even suicidal, as profit-oriented actors might easily opt to use unhealthy chemicals and substances in their food products for lower input cost and bigger revenue.

While libertarians say "markets will stabilize themselves through interactions between demand and supply", they don't talk about the cost and ramifications that will occur during these self-regulating processes. For example, according to the libertarian approach if the university tuition fees are so high that many people can't study there, then naturally universities will have to adjust and charge less to not lose profit. Therefore, after some time as the amount of payments will get lower, more people will be able to get enrolled. So, market forces will balance themselves and the issue will be solved. This approach on superficial layer seems quite logical and convincing. But there are some nuances; such as the duration of this back and forth not being instantaneous. It takes time to make such considerations, sometimes even long years. And as a result, mass numbers of people in this time lapse will suffer and be negatively impacted. Moreover, if the amount of the tuition fees is reduced, still there will be people who won't afford.

Libertarians claim because capitalism is comprised of voluntary transactions, any type of exploitation is unlikely. It is one of their biggest talking points when it comes to defending their opposition to minimum wage laws and freedom of contract for employers. But they overlook the plausibility of a situation where one may enter into a contract out of desperation. There are always people who severely lack financial resources for various reasons. Reasons such as being heavily in debt, striving to provide food for family and to pay for an expensive treatment or surgery, etc. There is a big quantity of people who live paycheck to paycheck, who might starve and become homeless without stable monthly salaries. In this case, the fact that transactions are voluntary doesn't mean exploitation is impossible. There could be an indirect coercion, willfully accepted exploitation.

Libertarians are quick to point to several developed countries such as Sweden or booming economies like Singapore which do not have any minimum wage requirements to prove such wage demands are unnecessary and even harmful. It is true that the mentioned countries, especially Sweden which is a social democracy with generous welfare programs, do not have such laws. However, libertarians do not depict a clearer and broader picture by failing to bring up further details on this issue. For example, although Sweden has no binding minimum wage laws, they have strong 
labor unions and workers' rights organizations with large influence on decision-making (The EU and the Swedish collective agreement model, 2015). But libertarians abhor trade unions; consider them threats because they sponsor strikes, and force companies to pay higher amounts of money. According to the libertarian thought, higher payments must be justified by market forces; any kind of artificial enforcement is unacceptable.

Libertarian idea of boycotting those who breach the law also has its limitations. There are just infinite number of private businesses and companies in the world that it would be surreal to think ordinary people can hinder all their harmful activities through merely expressing their discontent. The proponents of this idea must be perfectly honest to accept the improbability of such approach. Firstly, people naturally lack time, energy and resources to protest and boycott all the private entities continuously. And even though some public protests may halt some companies from committing unlawful and damaging activities, many of them will get away with what they do. Thus, incrementally the society and ecosystem may get harmed. From this perspective, the importance of regulations and existence of a higher committee which oversees the activities of private businesses seem significant.

Secondly, customers' disapproval of the code of conduct, safety principles and environmental policies of a company does not automatically warrant they will be refusing to purchase its products and services. As an example, there were well-founded reports that certain popular international corporations - Nike (Bain, 2017) and H\&M (Butler, 2016) were abusing laws, engaging in multiple wrongdoings such as employing under-age persons and not following safety principles in several undeveloped countries. However, their financial profit didn't get reduced as a result of public criticism of the issue. Because the truth is, if people like certain product or brand, and if this thing has a reputation for having high quality and being mainstream, consumers are likely to be consciously or unconsciously ignoring the disturbing information about it.

There are globally many logically faulty, irrational behaviors which can only be explained with being likable and having soft power. For example, overwhelming majority of Muslims and people living in the regions of Middle East and Africa highly disapprove of the Western foreign policy on their regions. They all criticize the West for its military interventions, "bad morals", "promiscuity" and "profanity". Yet according to statistics and many official data Muslims flee in great numbers to these regions they regard as abominable (Muslim Population Growth in Europe, 2017). It is because the West has soft power as Joseph Nye called it - the ability to propel others to your side without the use of direct force. This analogy once again proves that when something is in good quality and attractive, the morals often become of secondary importance.

Another reason why solely relying on boycotting would be ineffective is the possibility of being dependent of the products of firms who violate the laws. For example, many oil companies pollute the environment, yet people need fuel for their automatic vehicles to go to their daily lives. Many businesses require oil for manufacturing their own goods. It is used in the production process of variety of items and products; from clothes to cell phones, from cars to computers and other technological equipment. Considering all these factors, rejecting the oil use would impair the daily life and pose a great threat to economy. Hence logically not many people would be keen to do that. Besides, the idea of boycotting a company may entail the possibility of shutting it down, and as a result, workers may lose their jobs. Moreover, because closing and opening new businesses require time, the ones who live paycheck to paycheck would suffer and unemployment would rise.

Besides, in the absence of institutions with higher authority that check profit-oriented organizations, corrupt data regarding their work activities may be presented to the public. Wealthy companies may pay certain individuals to conduct forged research on the impact of their activities or pay mass media outlets to be silence on the issue.

The other case why this libertarian idea of boycotting may fall short is - there exist many things that once the damage is done, there is no return. For example, inhaling some toxic air because some corporation carelessly emitted into the atmosphere already harms the health. It is impossible to undo this. Different toxic chemicals when released into the air can cause serious health troubles, illnesses and even death. As the logic and rationality of this counter-argument overwhelm, many libertarians find themselves compelled to accept the seriousness of the unintended effects which occur as the by-product of certain actions to third parties - the notion which is also known as externalities. 
It is wise to have more regulations in some industries and activities. Such as in making airplanes, helicopters and in the construction of buildings where people's lives would be at stake even if some minor error has been made. Even the slightest possibility of compromising safety standards in such areas for the sake of individual liberties sounds preposterous and frightening.

Conclusions. Reducing the role of government to let individual liberties flourish is a cogent idea and contains irrefutable political wisdom. The rationale behind this argument, combined with the empirical evidence from various different periods of the history makes it appear even more valid. Even in the $21^{\text {st }}$ century, where statistically and empirically the amount of global conflicts is the fewest ever and the number of states and other actors who adhere to the values like democracy and liberalism are the most ever, it is not rare to see oppression and crime committed by governments. There are many authoritarian states who unfairly silence, jail and in some cases murder the opposition members, embezzle public money, strangle freedom of speech and religion, create artificial monopolies and oligarchy, and engage in other hideous and horrendous activities. And surely decreasing their role and authority would result in more freedom, less crimes and repression - overall increase in happiness.

However, getting rid of the external constraints or achieving negative freedom as mentioned earlier doesn't mean all the inequality and injustice are over, and the perfectly desirable outcome is achieved. Dismantling the big common authority, dispersing the power and giving it on the hands of individuals do not guarantee these individuals will always act fairly. Nor does it mean some innate injustices such as having physical disabilities, being born as orphan or homeless will be over. Since no one is able to choose which family they will be born into, which influences they will have, their early environment, their race, ethnicity, gender, sexual orientation and physical health, it is wise to address the challenges that may happen as a result of pure luck. And the main problem with the libertarian thinking occurs at this stage.

Although working hard, spending effort and taking action may make one's life better, it doesn't entirely translate to reality. According to many studies and research that were conducted in the U.S., people mostly stay in the same rung of income ladder as their parents. It means the economic circumstances of a family, roughly speaking, predetermine the economic prospects of their child in future. For example, according to one study by The Pew Charitable Trusts and the Russell Sage Foundation, the intergenerational income elasticity (IGE) is very high in a country like the U.S. where private market economy and capitalism dominate the economic discourse (Mitnik and Grusky, 2015). On the contrary, the countries like Denmark and Finland which have strong social safety programs, have low IGE - therefore they are more mobile (Intergenerational Income Mobility, n.d.).

The future doesn't promise any improvement in IGE for the U.S. either. With the advent of artificial intelligence and increased automation many jobs already declined, and this trend will continue in upcoming decades. There are many analysts who forecast shortage of employment opportunities despite big demand by labor, as a result of these technological developments. In such circumstance, the inevitability of universal basic income sounds more convincing, as too many people will be competing for limited number of jobs.

The libertarian negligence to the importance of the positive freedom and innate unfair starting points, together with the other mentioned controversial points, make the ideology and the whole movement appear opaque. Libertarians themselves firstly must figure out the insufficiencies and plausible dire consequences which may happen as the direct outcome of their approach.

To conclude, surely reducing the role of common big authority like government is sensible. There is a wit in not allowing the power to be accumulated on one hand, as human nature to dominate and gain profit, when is not controlled, may get in the way of individual liberties. Hence may make the system more oppressive and unjust. Although this approach can be held as true in principle, it must be simultaneously acknowledged that not all government interference is bad. Indeed it must be determined in which domains of public and social life the government intervention can be encouraged. 


\section{References}

Ashford, N. and Davies, S. (2011). A Dictionary of Conservative And Libertarian Thought. London: Routledge. 306 p. Bain, M. (2017). Nike Is Facing A new wave Of Anti-Sweatshop Protests. [online] Business-humanrights.org. URL: <https://www.business-humanrights.org/en/nike-is-facing-a-new-wave-of-anti-sweatshop-protests> [Accessed 5 March 2020].

Boaz, D. (2002). Toward Liberty: The Idea That Is Changing The World. Washington, D.C.: Cato Institute. 473 p. Brennan, J. (2012). Libertarianism: What Everyone Needs To know. New York: Oxford University Press. 232 p.

Butler, S. (2016). HEM Factories in Myanmar Employed 14-Year-Old Workers. [online] The Guardian. URL: <https:/ / www.theguardian.com/business/2016/aug/21/hm-factories-myanmar-employed-14-year-oldworkers> [Accessed 19 February 2020].

Encyclopedia Britannica. (2020). Liberalism. [online] URL: <https://www.britannica.com/topic/liberalism> [Accessed 28 February 2020].

Fackliga brysselkontoret. (2015). The EU And The Swedish Collective Agreement Model. [e-book] The Brussels Office of the Swedish Trade Unions, pp.4-8. URL: <https://www.fackligt.eu/wp-content/uploads/2015/02/ The-EU-and-the-Swedish-collective-agreement-model_webb.pdf $>$.

Heath, F. (2017). Invisible Hand. [online] Encyclopedia Britannica. URL: <https:/ / www.britannica.com/topic/ invisible-hand $>$ [Accessed 11 March 2020].

Kopel, D. (2016). Why the Anti-Tyranny Case For The 2Nd Amendment Shouldn't Be Dismissed So Quickly. [online] Vox. URL: <https://www.vox.com/2016/8/22/12559364/second-amendment-tyranny-militia-constitutionfounders $>$ [Accessed 20 February 2020].

Lloyd, S. and Sreedhar, S. (2019). Hobbes's Moral and Political Philosophy. [online] The Stanford Encyclopedia of Philosophy. URL: <https:// plato.stanford.edu/entries/hobbes-moral> [Accessed 3 March 2020].

Mitnik, P. and Grusky, D. (2015). Economic Mobility in The United States. [e-book] The Pew Charitable Trusts and the Russell Sage Foundation, pp.1-2. URL: <https://web.stanford.edu/ pmitnik/EconomicMobilityinth eUnitedStates.pdf $>$ [Accessed 25 February 2020].

Ontheissues.org. (2018). Libertarian Party on Education. [online] URL: <https://www.ontheissues.org/Celeb/ Libertarian_Party_Education.htm> [Accessed 3 March 2020].

Pew Research Center's Religion \& Public Life Project. (2017). Muslim Population Growth In Europe. [online] URL: <https://www.pewforum.org/2017/11/29/europes-growing-muslim-population>.

Rawls, J. (1999). A Theory of Justice. Cambridge (MA): Harvard University Press. 560 p.

Rockwell, L. (1990). The Case for Pale libertarianism. Liberty, 3 (3). $80 \mathrm{~s}$.

Rogers, J. (1988). The Impact of Policy Analysis. Pittsburgh: University of Pittsburgh Press. 213 p.

Safvio. (2007). Milton Friedman - Your Greed or Their Greed? [video] URL: <https://www.youtube.com/ watch?v=RWsx1X8PV_A> [Accessed 4 February 2020].

Smith, G. (2013). The System of Liberty: Themes in the History Of Classical Liberalism. New York: Cambridge University Press. 237 p.

The Conference Board of Canada. n.d. Intergenerational Income Mobility. [online] URL: <https://www. conferenceboard.ca/hcp/Details/society/intergenerational-income-mobility.aspx?AspxAutoDetectCookieS upport=1> [Accessed 21 February 2020].

User Clip, (2018). A Licence to Make Toast in Your Own Damn Toaster. [video] URL: <https:/ / www.c-span.org/ video/?c4713898/user-clip-licence-make-toast-damn-toaster> [Accessed 7 January 2020].

Van Dyke, V. (1995). Ideology and Political Choice: The Search For Freedom, Justice, And Virtue. New Jersey: Chatham House Publishers. 312 p.

\section{Summary}

Yagublu N. N. Is libertarianism the new future? Analyzing ideological and philosophical roots of the libertarian thought in the United States. - Article.

Libertarianism as a political ideology and movement has garnered big curiosity in American political discourse in recent years. This support was further solidified with the achievement of getting the most votes ever in the history of the Libertarian Party, in 2016 U.S. presidential election. This research paper thoroughly examines the characteristics, main concepts and criticism of the ideology by continuously providing detailed outlook on the important libertarian notions and elaborating the discussed ideas through carefully-thought, case by case examples.

The scientific work is multidimensional and multifaceted in its scope, and contains arguments with their counter-arguments to depict a broad, rational picture. Thus, the reader can see, fathom and compare the shortcomings and advantages of the talked ideas more effectively. 
Libertarian philosophy gives huge importance to the notions of liberty, freedom and individualism. Apart from this, another common thing that brings all libertarians together is their lack of trust to the government. Hence they always aspire to limit the role of it. Libertarians always emphasize the importance of free markets and vigorously express their discontent with any outside intervention to it, especially the one by the government. There are many different forms of libertarianism, some of them are more radical and support no-state structure. Libertarians, in principle, are not really concerned with inequality; they actually consider it positive to some extent.

Although on the surface level the rationale behind many libertarian ideas seems reasonable and convincing, the empirical evidence and analyzing the results of actions which occur as the direct implementation of these principles show the necessity of a more comprehensive and accommodating approach. As society, economy and governing are so interconnected and intertwined with each other, certain actions have unintended consequences and in long term may yield destructive effect. The empirical reality should be taken into account in order to formulate effective policies for the benefit of the people.

Key words: libertarianism, ideology, free market, individualism, behavioral economics

\section{Анотачія}

Ягублу Н. Н. Лібертаріанство - нове майбутнє? Аналіз ідеологічних і філософських коренів лібертаріанської думки в США. - Стаття.

Лібертаріанство як політична ідеологія і рух в останні роки викликає великий інтерес в американському політичному співтоваристві. Цей інтерес ще більше зміцнився з отриманням лібертаріанською партією на президентських виборах в США в 2016 році найбільшої кількості голосів у своїй історії. У цій статті докладно розглядаються характеристики, основні концепції лібертаріанства, дається критика ідеології, огляд основних лібертаріанському понять, аналіз обговорюваних ідей за допомогою ретельно продуманих конкретних прикладів.

Це дослідження багатогранне і багатоаспектне за своєю структурою і містить докази і контрдокази, щоб зобразити широку реальну картину розвитку лібертаріанства. В результаті читач може більш ефективно побачити, зрозуміти і порівняти недоліки і переваги обговорюваних ідей.

Філософія лібертаріанство надає виняткового значення поняттям свободи, волі й індивідуалізму. Крім цього, є ще одна спільна риса, яка об'єднує всіх лібертаріанців, - це відсутність довіри до уряду. Саме тому вони завжди прагнуть обмежити його роль. Лібертаріанці підкреслюють важливість вільного ринку і рішуче висловлюють своє невдоволення будь-яким втручанням у нього ззовні, особливо 3 боку уряду. $€$ безліч різних форм лібертаріанства, деякі з них більш радикальні і підтримують недержавні структури. Лібертаріанців насправді практично не хвилює нерівність, вони дійсно вважають це до певної міри позитивним.

На поверхневому рівні логічне обгрунтування багатьох лібертаріанських ідей здається розумним $\mathrm{i}$ переконливим, проте емпіричні дані й аналіз результатів дій, які відбуваються при безпосередньому застосуванні цих принципів, показують необхідність всеосяжного і гнучкого підходу. Оскільки суспільство, економіка й управління тісно взаємопов'язані і переплетені між собою, певні дії тут можуть мати непередбачені наслідки і в довгостроковій перспективі виробляти руйнівний ефект. Щоби сформулювати ефективну політику в інтересах людей, слід брати до уваги соціальну реальність.

Ключовi слова: лібертаріанство, ідеологія, вільний ринок, індивідуалізм, поведінкова економіка. 